研究課題別評価

1. 研究課題名 :モルフォゲンシグナル分子の濃度調節による病的組織の修復

2. 研究者氏名 安達 山田)卓

3. 研究の狙い:

<目標> がんの自然治癒といj立場からみた生体のもつ一つの戦略として、アポトーシスの誘 導を挙げることができる。アポトーシスとは、がん遺伝子やがん抑制遺伝子に傷害をもつた細胞は、 がん化する前にアポトーシスを起こして取り除かれる、という仕組みである。この現象に代表され るように、生体は異常組織を未然に取り除〈積極的な性質をもっていることが知られるが、いかな る種類の異常細胞も、同樣な方法で取り除くことかできるのかどうか？とい㵍題に答えるための 知識は、数年前まてほとんと得られていなかったと言って良い。しかしこの問題の重要さは、発生 生物学上の1テーマとしての意義に限定されず、体細胞突然変異に起因する樣々な疾患の予防 · 治療への発展や、自然免疫メカニズムの延長線上とい観点からも注目されるべきである。本研 究では、このような観点における研究の端緒として、位置情報を与えるモルフォゲンのシグナル強 度が異常となった細胞が、如何にして取り除かれるか？についての解明を目指した。

<目的> 未分化な組織か特殊化した形態や機能をもつ組織へと発展するための初期段階には、 モルフォゲンと呼ばれる細胞外物質からの刺激を受けることが必要である。モルフォゲンは未分 化な組織のご限られた部域で産生されて、乥れか組織全体へと拡散することによって作られる 濃度勾配が、各細胞の分化方向を運命付ける位置情報をもたらすと考えられている。もしもモル フォゲの濃度勾配が崩れると、あるいはモルフォゲンが惹き起こすシグナル伝達強度が強まっ たに弱まったりして正常值から外れると、組織は異常形態を形成してしまうが、一方て組織には異 常発生を認識し、アポトーシスによって关れを破壊しながら正常形態へと修復していく機構が備わ っている。本研究課題では、このような状況のモデルとしてショウジョウバ士の翅におけるモルフォ ゲン Dpp Decapentaplegic)を扱い、異常形態の修復過程が包含する細胞応答と分子機構の探 求を試みた。

＜解決すべき問題 > ショウジョウバ翅原基上にモルフォゲンシグナルである Dpp シグナルの 異常が起きた細胞を作り出す際に、組織全体が異常になった時と、正常組織の中に異常細胞が

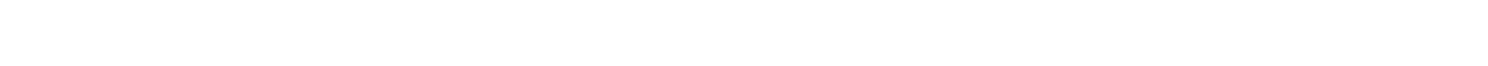
えられるかどうかの検証が必要であつた Hh シグナルに対する依存性の違いから最終的に別現 象とい結論に到達している)。またアポトーシスシグナルとして、ストレス応答性のシグナル伝達 因子JNKの活性を検出することを考えた。JNKのシグナルが一部のアポトーシス誘導に必要であ るという事実は、現在では常識化したと考えられるが、本研究が開始された当初、光れに対する 認識は高いものではなかった。关こで、従来からアポトーシス誘導分子として知られる Caspase- 3 の活性とJNK 活性を同時に検出して、両者を比較検討した。

<問題解決へのアプローチ> 結果から見ると、異常細胞を取り除〈ための非自律的細胞死 
Morphogenetic Apoptosis」の発見には、Caspase-3活性よりもJNK 活性を観察する事が決定的 に重要であつた。JNK 活性を見るためには、JNK 活性化によって転写誘導される事が知られる遺 伝子 puckeredの発現を検出し、またれがJNK活性化因子 Hemipterous (=MKK7)の突然変異体 バックグラウントでは消失することを、実験毎に一つ一つ確認した。一方、Caspase- 3 の活性化を 見るために、現在では市販されているが当時は入手困難であつた抗 Human Cleaved Caspase- 3 抗体の譲渡を、IDUN Pharmaceutical 社 アメリカ)と交渉の上に受けることかできた。

\section{4. 研究結果：}

Dpp シグナルは、本来は翅原基の中央部でシグナル強度が高い。これを低〈する操作を行うと、 翅原基の中央部は異常な発生運命 翅原基の周辺部としての運命)をたどるが、乥れだけでなく、 この時細胞死誘導性のタンパク質リン酸化酵素 JNK の活性化が起きて細胞が除去される。周辺 細胞のうち、なぜ翅原基の中央部にあるものだけが除去されるのかを説明するために、中央部に だけ存在するもう一つのモルフォゲン Hh Hedgehog、短距離拡散性)に着目した。通常中央部で は常にDpp シグナルもHh シグナルもどちらも高く、周辺部ではどちらもが低い。㫕こで、中央部で Dpp シグナルが低〈なった状況に加え、さらにHh シグナルも低くなつた状況をもたらしたところ、細 胞死は完全に抑圧された。つまり複数のモルフォゲンシグナルのバランスか乱れるとアポトーシス が起きるようにプログラムされており、乥れが異常細胞の除去につながっていることが示された。

一方、野生型の組織の中に Dpp シグナル伝達因子突然変異体のクローンを作成すると、突然 変異体クローンと周辺の野生型細胞との境界線を中心として、光の両側 ゆローン内外)て細胞死 誘導性のタンパク質リ酸化酵素 JNK の活性化が見られる。つまり、本来緩やかなスロープを作 るべきモルフォゲン活性勾配の中に大きな段差が生じると、段差の両側の細胞が段差の存在を 認識して、光の細胞から順次遠方の細胞へと JNK を活性化して細胞死を導き始め、最終的に突 然変異体クローンを完全に除去して、緩やかなモルフォゲン活性勾配を再び出現させる。この現 象は、体細胞突然変異などによって生じた異常細胞を除去し、正常形態形成を保証するために獲 得されたメカニズムと考えられ、Morphogenetic Apoptosis と名付けられた。

この現象、Morphogenetic Apoptosis は、異常レベルのモルフォゲン刺激を受容したために、誤 つた発生運命を進行させていく悪性のクローンを組織内で検出し、除去するためのメカニズムであ り、体細胞突然変異に起因する異常形態の自然治癒には必須の細胞応答で、正常発生を保証し ていると考えられる。しかし、Morphogenetic Apoptosisの存在意義は、単にモルフォゲン活性勾配 のスロープの修復にとどまらず、生体内に発生する樣々な異常細胞集団 例えば、環境污染物質 に曝露された細胞や発癌初期における变異細胞クローンなど)の検出と排除にも使われている可 能性がある。今後は光れら、Morphogenetic Apoptosis が活用される生体内現象や疾患を広〈探 索するほか、如何なる分子が正常細胞とのコミュニケーションに用いられ、細胞死シグナルの発 生と伝播に関与するのかなどの問題について取り組み、研究を発展させてい計画である。

\section{5. 自己評価 :}

モルフォゲンシグナルのレベルが異常となつた細胞がいつのまにか除去される現象自体はか つてから知られていたが、組織内部にはもともとモルフォゲンシグナルのレベルが高い細胞と低 
い細胞が存在しているのになぜ異常レベルの細胞の除去が可能になるのかは問題視されたこ とが沏た。一言で言うと、弚の方法について調べたのが本研究である。研究を開始して直ちに 判明した事は、モルフォゲンシグナルレベルが異常になつた細胞のみが徐々に細胞死していく取 (除かれていくのではなく、レベルの非常に異なる細胞が隣接すると、両者が異常事態を認識し て細胞死を起こし、光れが繰り返された結果、異常な細胞を取り除くことが可能となる、という全く 予想されたこともないメカニズムであった。しかし、关れはモルフォゲンシグナルレベルが高い細 胞と低し 細胞の両方が存在している状況下で異常細胞を発見するには、この方法以外には有り 得ないのではないか? というくいの極めて合理的なメカニズムであり、さらに、生体内に起こり得 る樣々な種類の異常細胞の除去においても適用されている可能がある、言わば多くの普遍性が 期待される非常に意義の大きいしくみの発見であったと考えている。

しかし、研究成果公表に至るまでの流れと光の後の発展の困難さには、正直な所感として満足 できない面が多々あつた。まず、この研究成果の斬新さ、意義、面白さ、発展性、光ういった実質 面がレビューワーからまった 評価されず、多〈の研究者が目にするメジャー・ジャーナルへの揭 載ができなかったのは残念な体験であった。レビューワーからは、あるいは逆に評価されたのか も知れないが、膨大な時間と労力を要する要求を突き付けられ、光れに正面から応えるべくこちら が1年以上苦闘している間に、結論が似かよったシンプルな実験結果が大御所からハイレベルジ ヤーナルに出された。実はこれは長引くリバイスの過程から大いに色惧していたことで、論文が受 け入れないのならジャーナルではなく、インターネット上で私的に論文を公開してプライオリティー を確保できないか、とまで半ばノイローゼ的に考えたりもしたが、最終的には光のような非常識な 行いをする度胸ももつことはできなかった。今冷静に振り返ってみて、提出する論文にはなるべく スキを見せない細心の注意が必要であることを戒めとして学ぶことができたし、尋常でないリバイ スを求められた時に打つべき次の手段を予め考えておく入念さなど、研究とは別次元の技術が、 現実問題として重要であることも学んだ。上記の競合論文の内容が、我々のものとは随分異質で あることを、せめて幸いに思いたいと考えている。

次にこの研究は、1997年ごろに私が日本で行っていた研究か端緒となり、さらにアメリカへ留学 中に自由な発想のもとに始めさせてもらつた実験に直接由来している。留学中、日本からサラリー をもらっていたために炎のような自由を与えて下さった留学先の教授 Michael B. O'Connor 氏に謝 意を表すべく彼にCorresponding Author となっていただいた。しかし、自分でジャーナルと交渉し ない分、最終的に論文の内容やエディタへの対応に必ずしも満足できない面が残ってしまったこと は事実である。謝意と責任所在はもちろん別件であり、自らの責任で行った研究はやはり自らが Corresponding Author になるべきもの、と今は考えている。

最後に研究乥のものの内容についてであるが、Morphogenetic Apoptosis を誘発 伝播する細 胞間シグナルが何であるか、この最も単純で大きな興味を解決することが、未だに全くできていな いことが極めて残念である。これをスクリーンする方法にいくか手出ししてみたが、簡単に言うと、 異常細胞が残ってしま湥然変異体 サプレッサー)」というのが光も光㨖命的に弱く、突然変 異誘発が成功しても系統化できないというジレンマが生じて研究が持続できない。光こで、従来型 のサプレッサー突然変異体スクリーンとはまった〈異なるアイデアを考え出して取り組むべき問題 
である、と現在兴の方法を模索中である。

以上のように本研究の成果には、極めて満足できる面と全〈乥うでない面との両方があるため、 弚うでな面の今後の成果を切望して、私自らの自己評価点を5段階評価の「」としたいと考え ている。

\section{6. 研究総括の見解 :}

動物の個体が关の多細胞体制を構築し維持する上で、不必要あるいは異常となつた細胞を排 除する現象は古くか知られ研究されてきた。本研究はこの課題に独創的に取り組み、異常細胞 を排除するための非自律的細胞死を発見し、morphogenetic apoptosis と定義付け、炎の仕組み の大要を明らかにした。この成果は研究の更なる発展を担保すると共に、傷害やがんの克服にも 応用しうる新技術の開発にも結びつくものとして高〈評価できる。ただ、個人研究であることを深く 自覚し、論文発表の際の correspondence にはより責任を持つことが望まれる。

\section{7. 主な論文等：}

主な論文

1. Adachi- Yamada, T.; puckered- GAL4 driving in J NK- active cells. Genesis, 34, 19- 22 (2002).

2. Adachi- Yamada, T. and O'Connor, M.B.; Morphogenetic apoptosis; A mechanism correcting discontinuities in morphogen gradients. Dev. Biol., 251, 7490 (2002).

\section{口頭発表}

1. 安達 卓, Michael B. O'Connor :Morphogenetic Apoptosis: モルフォゲンシグナル勾配の不連 続を修復する細胞死.第 25 回日本分子生物学会年会 2002)横浜 .

2. Adachi- Yamada, T. and Michael B. O'Connor.: Morphogenetic Apoptosis: a mechanism for correcting discontinuities in morphogen gradients. Keystone Symposia (2003) Keystone, USA.

3. 安達 卓, Mark Stapleton, Michael B. O'Connor :ショウジョウバエの Dpp シグナル抑制因子/ アポトーシス誘導因子としての Taip6.日本発生生物学会第 36 回大会 2003)札幌 .

4. 春本 敏之, 上田 龍, 西鄉 薰, 安達 卓 :ダイオキシンレセプターのショウジョウバエホモロ グ Spineless の活性化が導〈アポトーシスの 性質について.日本発生生物学会第 36 回大会 2003)札幌 .

5. Adachi- Yamada, $\mathrm{T}$.: Roles of morphogenetic apoptosis during imaginal disc development . 第 2 回日韓ショウジョウバエシンポジウム 2003)東京 .

6. 春本 敏之, 安達 卓 :Molecular basis of distance- dependent variation of nonautonomous apoptosis mediated by by Ras.日本ショウジョウバ研究会第 6 回研究集会 2003)東京.

7. 大庭圭介, 春本敏之, 安達 卓 :モルフォゲン Dpp のシグナルレベルの異常か誘導する細胞 死のメカニズム.第 26 回日本分子生物学会年会 2003)神戶.

8. Harumoto, T. and Adachi- Yamada, T.: Distance- dependent variation of apoptotic responses caused by activated Ras in Drosophila wing. Keystone Symposia (2004) Snowbird, USA. 